\title{
BULLETIN OF THE NEW ZEALAND SOCIETY FOR EARTHQUAKE ENGINEERING
}

\author{
3-YEAR INDEX \\ 1999-2001
}

Key to Bulletin Issues:

$\begin{array}{lll}\text { Vol. } & \text { 32, No.1 } & \text { March } \\ 32(2) & \text { June } \\ 32(3) & \text { September } \\ 32(4) & \text { December } \\ & \\ 33(1) & \text { March } \\ 33(2) & \text { June } \\ 33(3) & \text { September } \\ 33(4) & \text { December } \\ & \\ 34(1) & \text { March } \\ 34(2) & \text { June } \\ 34(3) & \text { September } \\ 34(4) & \text { December }\end{array}$

\section{AUTHOR INDEX}

A.

Arya, A.S. Non-engineered construction in developing countries- an approach toward earthquake risk prediction.

33(3) 187

B.

Barnett, A. see Goldsmith, P.

Beattie, G. see Beetham, D.

$34(4)$

Beetham, D. : Beattie, G.: Earl, B.: Duncan, D. NZ Society for Earthquake Engineering Reconnaissance Team to Seattle, USA: The February 28, 2001 Nisqually Earthquake. 34(4) 253

Berrill, J.B. see Davis, R.O. $34(2)$

Berryman, K.R. see Downes, G.L.

Berryman, K. see Stirling, M.

Bradshaw, D. see Sharpe, R.D.

$33(2)$
Brown, N. see Sharpe, R.D.

$33(2)$

Brunsdon, D. NZSEE President's Page 33(2)

Brunsdon, D.R.: Davey, R.A.: Graham, C.J.: Sidwell, G.K.: Villamor, P.: White, R.H.: Zhao, J.X. The Chi-Chi, Taiwan Earthquake of 21 September $1999 . \quad 33(2) 105$

Bubb, C.T.J. Earthquake engineering in Australia before Meckering and after Newcastle. 32(1) 13

Buckle, I.G. Passive control of structures for seismic loads. 33(3) 209

Bull, D.K. see Singh, S.S. $32(2)$

C.

Carr, A.J. see Crisafulli, F.J. $33(1)$

Carr, A.J. see Rahman, A.M. $34(1)$

Chadwick, M. see Kozuch, M.J.

Charleson, A.W. A progress report on the Earthquake Hazard Centre.

32(4) 257

Charleson, A.W.: Fyfe, G.D. Earthquake building damage in developing countries: a review of recent reconnaissance reports. $34(2) 158$

Cooke, N. see Singh, S.S.

$32(2)$

Cousins, W.J. : Zhao, J.X.: Perrin, N.D. A model for the attenuation of peak ground acceleration in New Zealand earthquakes based on seismograph and accelerograph data. 32(4) 193

Cowan, H.A. see Restrepo, J.I.

$33(1)$

Crisafulli, F.J.: Carr, A.J.: Park, R. Analytical modelling of infilled frame structures - a general review. 
D.

Davenport, P.N. see Zhao, J.X.

Davenport, P.N. see Dowrick, D.J.

Davey, R.A. see Brunsdon, D.R.

Davidson, B.J. see Fenwick, R.C.

Davidson, B.J. see Ingham, J.M.

Davis, R.O.: Berrill, J.B. Liquefaction at the Imperial Valley Wildlife site.

34(2) 91

Deam, B.L. Seismic ratings for degrading structural systems. 34(3) 214

Dely, R. see Fenwick, R.C.

Downes, G.L.: Dowrick, D.J.: Smith, E.G.C.: Berryman, K.R. The 1934 Pahiatua Earthquake sequence: analysis of observational and instrumental data. 32(4) 221

Downes, G.L.: Dowrick, D.J.: Van Dissen, R.J.: Taber, J.J.: Hancox, G.T.: Smith, E.G.C. The 1942 Wairarapa, New Zealand, Earthquakes: analysis of observational and instrumental data.

34(2) 125

Downes, G. see Pettinga, J.R.

34(4)

Dowrick, D.J. see Rhoades, D.A.

Dowrick, D.J.: Rhoades, D.A. Attenuation of Modified Mercalli Intensity in New Zealand earthquakes. 32(2) 55

Dowrick, D.J. see Downes, G.L.

Dowrick, D.J. see Downes, G.L.

Dowrick, D.J.: Rhoades, D.A.: Davenport, P.N. Damage ratios for domestic property in the Magnitude 7.21968 Inangahua, New Zealand, Earthquake. 34(3) 191

Duncan, D. see Beetham, D.

E.

Earl, B. see Beetham, D.
Elliott, S. see Goldsmith, P.

$32(2)$

F.

Fenwick, R.C.: Dely, R.: Davidson, B.J. Ductility demand for uni-directional and reversing plastic hinges in ductile moment resisting frames.

32(1) 1

Fyfe, G.D. see Charleson. A.W.

G.

Garcia, S.R. see Romo, M.P.

Goff, J. see Goldsmith, P.

Goldsmith, P.: Barnett, A.: Goff, J.: McSaveney, M.: Elliott, S.: Nongkas, M. Report of the New Zealand Reconnaissance Team to the area of the $17^{\text {th }}$ July 1998 Tsunami at Sissano Lagoon, Papua New Guinea. 32(2) 102

Graham, C.J. see Brunsdon, D.R.

H.

Hancox, G.T. see Downes, G.L.

Holmes, W.T. Risk assessment and retrofit of existing buildings.

$33(3) 222$

I.

Ingham, J.M. see To, N.H.T.

$33(3)$

Ingham, J.M.: Liddell, D.: Davidson, B.J. Influence of loading history on the response of a reinforced concrete beam.

34(2) 107

J.

Jigyasu, R. From natural to cultural disaster: consequences of the post-earthquake rehabilitation process on the cultural heritage in Marathwada region, India. 34(3) 237

Johnston, D. see Manville, V. $33(4)$ 
K.

Kameda, H. Engineering management of lifeline systems under earthquake risk. 33(3) 248

Kawashima, K. Seismic design and retrofit of bridges. 33(3) 265

King, A.B. Report on attendance at ISO TC 98 'Bases for actions on structures', held in Washington DC, $14^{\text {th }}$ to $19^{\text {th }}$ May 2001 . 34(3) 244

Kingsbury, P.A.: Pettinga, J.R.: Van Dissen, R.J. Earthquake hazard and risk assessment study for the Canterbury region: Outline of programme development.

34(4) 276

Kircher, C.A. United States building code approach to variations in regional seismicity. $33(1) 48$

Kirkcaldie, D. see Sharpe, R.D.

Kowalsky, M.J. see Priestley, M.J.N.

Kozuch, M.J.: Chadwick, M. Azimuthal and regional variations of coda waves in New Zealand.

L.

Liddell, D. see Ingham, J.M.

Liu, A.: Park, R. Seismic behaviour and retrofit of pre1970's as-built exterior beam-column joints reinforced by plain round bars. $\quad 34$ (1) 68

M.

Manville, V.: Johnston, D.: Stammers, S.: Scott, B. Comparative preparedness in New Zealand and the Philippines for response to, and recovery from, volcanic eruptions: case studies from the 1991 Pinatubo eruption and the 1995-96 eruptions of Ruaphehu. 33(4) 445

Mattingly, S. Advances in seismic risk management in developing countries.

33(3) 286

McGinty, P. Preparation of the New Zealand earthquake catalogue for a probabilistic seismic hazard analysis.

34(1) 60
McManus, K.J. see Sharpe, R.D.

$33(2)$

McSaveney, M. see Goldsmith, P.

McVerry, G.H. see Zhao, J.X.

Medoza, M.J. see Romo, M.P.

Megget, L.M. Editorial

32(4) Unpaged

Moss, P.J. see Rahman, A.M.

N.

Nongkas, M. see Goldsmith, P.

P.

Pancha, A.: Taber J. Weak motion attenuation of peak ground acceleration in the North Island, New Zealand. $32(3) 125$

Park, R. see Crisafulli, F.J.

$33(1)$

Park, R. Brief report from the 12WCEE Organising Committee.

33(2) 169

Park, R. Brief report on the $12^{\text {th }}$ World Conference on Earthquake Engineering, held in Auckland, New Zealand during 30 January - 4 February 2000.

33(3) 177

Park, R. Improving the resistance of structures to earthquakes. 34 (1) 1

Park, R. see Liu, A.

$34(1)$

Paulay, T. Understanding torsional phenomena in ductile systems. 33(4) 403

Perrin, N.D. see Cousins, W.J.

Pettinga, J.R. see Kingsbury, P.A.

Pettinga, J.R.: Yetton, M.D.: Van Dissen, R.J.: Downes, G. Earthquake source identification and characterisation for the Canterbury region, South Island, New Zealand. $\quad 34(4) 282$

Pettinga, J.R. see Stirling, M.

Pham, T. see Sharpe, R.D. $33(2)$ 
Pinto, P.E. Design for low/moderate seismic risk.

Priestley, M.J.N. Performance based seismic design.

$$
\text { 33(3) } 325
$$

Priestley, M.J.N.: Kowalsky, M.J. Direct displacementbased seismic design of concrete buildings.

33(4) 421

R.

Rahman, A.M.: Carr, A.J.: Moss, P.J. Seismic pounding of a case of adjacent multiple-storey buildings of differing total heights considering soil flexibility effects. 34(1) 40

Restrepo, J.I.: Cowan, H.A. The "Eje Cafetero" Earthquake, Colombia of January 251999.

33(1) 1

Reyners, M. Quantifying the hazard of large subduction thrust earthquakes in Hawke's Bay. 33(4) 477

Rhoades, D.A.: Dowrick, D.J. Station correction analysis for surface-wave magnitudes of New Zealand earthquakes. 32(1) 21

Rhoades, D.A. see Dowrick, D.J.

Rhoades, D.A. see Dowrick, D.J.

$34(3)$

Romo, M.P.: Mendoza, M.J.: Garcia, S.R. Geotechnical factors in seismic design of foundations, stateof-the-art report. 33(3) 347

S.

Scott, B. see Manville, V.

Scott, E.F. A report on the relief organisation in Hastings arising out of the [Magnitude 7.8] Earthquake in Hawke's Bay [New Zealand] on February 3, 1931. 32(4) 246

Sharpe, R.D.: Bradshaw, D.: Brown, N.: Van Dissen, R.: Kirkcaldie, D.: McManus, K.J.: Pham, T.: Stevenson, C. Marmara Sea Earthquake Reconnaissance Report. 33(2) 65

Sidwell, G.K. see Brunsdon, D.R.

$33(2)$
Singh, S.S.: Cooke, N.: Bull, D.K. Out-of-plane performance of a partially filled reinforced masonry wall with Ribraft ${ }^{\mathrm{TM}}$ floor. 32(2) 90

Smith, E.G.C. see Downes, G.L.

Smith, E.G.C. see Downes, G.L.

Somerville, P. Seismic hazard evaluation. 33(3) 371

Somerville, P. Addendum: Figures for the 12WCEE state-of-the-art paper "Seismic hazard evaluation" published in Vol. 33, No. 3, September 2000, pp325-346. 33(4) 484

Soong, T.T.: Spencer, B.F. Active, semi-active and hybrid control of structures. $\quad 33(3) 387$

Spencer, B.F. see Soong, T.T. 33(3)

Sritharan, S. see To, N.H.T. 34(3)

Stammers, S. see Manville, V. 33(4)

Stevenson, C. see Sharpe, R.D. 33(2)

Stirling, M.: Pettinga, J.R.: Berryman, K.: Yetton, M.D. Probabilistic seismic hazard assessment of the Canterbury region, New Zealand. 34(4) 318

T.

Taber, J. see Pancha, A.

Taber, J.J. see Downes, G.L.

To, N.H.T.: Ingham, J.M.: Sritharan, S. Monotonic nonlinear analysis of reinforced concrete knee joints using strut-and-tie computer models. 34(3) 169

V.

Van Dissen, R. see Sharpe, R.D.

Van Dissen, R.J. see Downes, G.L.

Van Dissen, R.J. see Kingsbury, P.A.

Van Dissen, R.J. see Pettinga, J.R.

$34(4)$ 
Villamor, P. see Brunsdon, D.R

W.

White, R.H. see Brunsdon, D.R.

Y.

Yetton, M.D. see Pettinga, J.R.

Yetton, M.D. see Stirling, M.

\section{Z.}

Zhao, J.X.; Davenport, P.N.: McVerry, G.H. Modelling and earthquake response of Gisborne Post office site, New Zealand. 32(3) 146

Zhao, J.X. see Cousins, W.J.

Zhao, J.X. see Brunsdon, D.R.

\section{SUBJECT INDEX}

\section{Addendum}

Figures for the 12WCEE state-of-the-art paper "Seismic hazard evaluation" published in Vol. 33, No. 3, September 2000, pp325-346. Somerville, P.

$$
\text { 33(4) } 484
$$

Base Isolation - see Earthquake engineering

\section{Bridges}

Monotonic non-linear analysis of reinforced concrete knee joints using strut-and-tie computer models. To, N.H.T.: Ingham, J.M.: Sritharan, S.

$$
\text { 34(3) } 169
$$

Seismic design and retrofit of bridges. Kawashima, K. 33(3) 265

\section{Buildings}

Analytical modelling of infilled frame structures - a general review. Crisafulli, F.J.: Carr, A.J.: Park, $\mathrm{R}$.

33(1) 30

Damage ratios for domestic property in the Magnitude 7.21968 Inangahua, New Zealand, Earthquake. Dowrick, D.J.: Rhoades, D.A.: Davenport, P.N. 34(3) 191

Improving the resistance of structures to earthquakes. Park, R. 34(1) 1

Risk assessment and retrofit of existing buildings. Holmes, W.T.

Seismic behaviour and retrofit of pre-1970's as-built exterior beam-column joints reinforced by plain round bars. Liu, A.: Park, R. $\quad 34(1) 68$

Seismic pounding of a case of adjacent multiple-storey buildings of differing total heights considering soil flexibility effects. Rahman, A.M.: Carr, A.J.: Moss, P.J. 34(1) 40

Understanding torsional phenomena in ductile systems. Paulay, T. 33(4) 403

Codes see Standards

\section{Conferences and seminars}

Brief report from the $12 \mathrm{WCEE}$ Organising Committee. Park, R. 33(2) 169

Brief report on the $12^{\text {th }}$ World Conference on Earthquake Engineering, held in Auckland, New Zealand during 30 January - 4 February 2000. Park, R. 33(3) 177

Report on attendance at ISO TC 98 'Bases for actions on structures', held in Washington DC, $14^{\text {th }}$ to $19^{\text {th }}$ May 2001. King, A.B. $34(3) 244$

\section{Disaster relief}


A report on the relief organisation in Hastings arising out of the [Magnitude 7.8] Earthquake in Hawke's Bay [New Zealand] on February 3, 1931.

Scott, E.F.

32(4) 246

Comparative preparedness in New Zealand and the Philippines for response to, and recovery from, volcanic eruptions: case studies from the 1991 Pinatubo eruption and the 1995-96 eruptions of Ruaphehu. Manville, V.: Johnston, D.: Stammers, S.: Scott, B. 33(4) 445

\section{Earthquake damage}

Damage ratios for domestic property in the Magnitude 7.21968 Inangahua, New Zealand, Earthquake. Dowrick, D.J.: Rhoades, D.A.: Davenport, P.N. 34(3) 191

Earthquake building damage in developing countries: a review of recent reconnaissance reports. Charleson, A.W.: Fyfe, G.D. $\quad 34(2) 158$

From natural to cultural disaster: consequences of the post-earthquake rehabilitation process on the cultural heritage in Marathwada region, India. Jigyasu, R.

34(3) 237

Marmara Sea Earthquake Reconnaissance Report. Sharpe, R.D.: Bradshaw, D.: Brown, N.: Van Dissen, R.: Kirkcaldie, D.: McManus, K.J.: Pham, T.: Stevenson, C. 33(2) 65

The "Eje Cafetero" Earthquake, Colombia of January 25 1999. Restrepo, J.I.: Cowan, H.A. 33(1) 1

\section{Earthquake engineering}

Active, semi-active and hybrid control of structures. Soong, T.T.: Spencer, B.F. 33(3) 387

Analytical modelling of infilled frame structures - a general review. Crisafulli, F.J.: Carr, A.J.: Park, R. 33(1) 30

Design for low/moderate seismic risk. Pinto, P.E. 33(3) 303

Direct displacement-based seismic design of concrete buildings. Priestley, M.J.N.: Kowalsky, M.J.
Ductility demand for uni-directional and reversing plastic hinges in ductile moment resisting frames. Fenwick, R.C.: Dely, R.: Davidson, B.J. 32(1) 1

Earthquake engineering in Australia - before Meckering and after Newcastle. Bubb, C.T.J. 32(1) 13

Geotechnical factors in seismic design of foundations, state-of-the-art report. Romo, M.P.: Mendoza, M.J.: Garcia, S.R.

33(3) 347

Improving the resistance of structures to earthquakes. Park, R. 34(1) 1

Influence of loading history on the response of a reinforced concrete beam. Ingham, J.M.: Liddell, D.: Davidson, B.J. $\quad 34(2) 107$

Monotonic non-linear analysis of reinforced concrete knee joints using strut-and-tie computer models. To, N.H.T.: Ingham, J.M.: Sritharan, S.

34(3) 169

Out-of-plane performance of a partially filled reinforced masonry wall with Ribraft ${ }^{\mathrm{TM}}$ floor. Singh, S.S.: Cooke, N.: Bull, D.K. 32(2) 90

Passive control of structures for seismic loads. Buckle, I.G. 33(3) 209

Performance based seismic design. Priestley, M.J.N 33(3) 325

Report on attendance at ISO TC 98 'Bases for actions on structures', held in Washington DC, $14^{\text {th }}$ to $19^{\text {th }}$ May 2001. King, A.B.

$34(3) 244$

Seismic behaviour and retrofit of pre-1970's as-built exterior beam-column joints reinforced by plain round bars. Liu, A.: Park, R. $\quad 34$ (1) 68

Seismic design and retrofit of bridges. Kawashima, K. 33(3) 265

Seismic pounding of a case of adjacent multiple-storey buildings of differing total heights considering soil flexibility effects. Rahman, A.M.: Carr, A.J.: Moss, P.J. 34(1) 40

Understanding torsional phenomena in ductile systems. Paulay, T. 33(4) 403 
United States building code approach to variations in regional seismicity. Kircher, C.A. 33(1) 48

\section{Earthquakes general}

The "Eje Cafetero" Earthquake, Colombia of January 25 1999. Restrepo, J.I.: Cowan, H.A. 33(1) 1

World earthquake of magnitude 6.0 or greater:

- November 1998 - December 1998 $32(1) 40$

- January to March 1999

- April to May 1999

- July - September 1999

- October - December 1999

$33(1) 57$

- January - April 2000

- April 18 - August 2000 33(4) 494

- September - December 2000 34(1) 83

- January - March 2001 34(2) 165

- April - June 2001 34(3) 249

- July - September 2001

34(4) 342
- April to June 1999 $32(3) 190$

- July to September 1999 $32(4) 263$

- 1999 October - December $33(1) 60$

- January - April 2000 33(2) 173

- May - August 2000 $33(4) 498$

- September - December 2000 34(1) 87

- January - March 2001 34(2) 167

- April - June 2001 34(3) 251

- July - September 2001 34(4) 343

Station correction analysis for surface-wave magnitudes of New Zealand earthquakes. Rhoades, D.A.: Dowrick, D.J. 32(1) 21

The 1934 Pahiatua Earthquake sequence: analysis of observational and instrumental data. Downes, G.L.: Dowrick, D.J.: Smith, E.G.C.: Berryman, K.R.

32(4) 221

The 1942 Wairarapa, New Zealand, Earthquakes: analysis of observational and instrumental data. Downes, G.L.: Dowrick, D.J.: Van Dissen, R.J.: Taber, J.J.: Hancox, G.T.: Smith, E.G.C.

$34(2) 125$

\section{Earthquakes in New Zealand}

A report on the relief organisation in Hastings arising out of the [Magnitude 7.8] Earthquake in Hawke's Bay [New Zealand] on February 3, 1931. Scott, E.F.

32(4) 246

Damage ratios for domestic property in the Magnitude 7.21968 Inangahua, New Zealand, Earthquake. Dowrick, D.J.: Rhoades, D.A.: Davenport, P.N. 34(3) 191

Quantifying the hazard of large subduction thrust earthquakes in Hawke's Bay. Reyners, M.

Significant New Zealand Earthquakes:

- November 1998 to December 1998

$32(1) 41$

- January to March 1999

$32(2) 123$

\section{Earthquake mitigation}

A progress report on the Earthquake Hazard Centre. Charleson, A.W. 32(4) 257

Earthquake risk (includes risk management)

Advances in seismic risk management in developing countries. Mattingly, S. $33(3) 286$

Design for low/moderate seismic risk. Pinto, P.E. 33(3) 303

Earthquake hazard and risk assessment study for the Canterbury region: Outline of programme development. Kingsbury, P.A.: Pettinga, J.R.: Van Dissen, R.J. 
Earthquake source identification and characterisation for the Canterbury region, South Island, New Zealand. Pettinga, J.R.: Yetton, M.D.: Van Dissen, R.J.: Downes, G. 34(4) 282

Non-engineered construction in developing countries- an approach toward earthquake risk prediction. Arya, A.S.

33(3) 187

Preparation of the New Zealand earthquake catalogue for a probabilistic seismic hazard analysis. McGinty, P. 34(1) 60

Probabilistic seismic hazard assessment of the Canterbury region, New Zealand. Stirling, M.: Pettinga, J.R.: Berryman, K.: Yetton, M.D.

34(4) 318

Risk assessment and retrofit of existing buildings. Holmes, W.T. 33(3) 222

\section{Editorials and leading articles}

Editorial. Megget, L.M.

32(4) Unpaged

NZSEE President's Page. Brunsdon, D. 33(2) i

\section{General}

From natural to cultural disaster: consequences of the post-earthquake rehabilitation process on the cultural heritage in Marathwada region, India. Jigyasu, R. 34(3) 237

\section{Geomechanics/Geotechnical engineering}

Geotechnical factors in seismic design of foundations, state-of-the-art report. Romo, M.P.: Mendoza, M.J.: Garcia, S.R. 33(3) 347

Liquefaction at the Imperial Valley Wildlife site. Davis, R.O.: Berrill, J.B. $34(2) 91$

Modelling and earthquake response of Gisborne Post office site, New Zealand. Zhao, J.X.; Davenport, P.N.: McVerry, G.H. 32(3) 146

Seismic pounding of a case of adjacent multiple-storey buildings of differing total heights considering soil flexibility effects. Rahman, A.M.:

Carr, A.J.: Moss, P.J. 34(1) 40

\section{Lifelines}

Engineering management of lifeline systems under $\begin{array}{ll}\text { earthquake risk. Kameda, H. 33(3) } 248 & \end{array}$

\section{Masonry}

Analytical modelling of infilled frame structures - a general review. Crisafulli, F.J.: Carr, A.J.: Park, R.

33(1) 30

Out-of-plane performance of a partially filled reinforced masonry wall with Ribraft ${ }^{\mathrm{TM}}$ floor. Singh, S.S.: Cooke, N.: Bull, D.K. 32(2) 90

\section{Modified Mercalli intensity}

Attenuation of Modified Mercalli Intensity in New Zealand earthquakes. Dowrick, D.J.: Rhoades, D.A.

32(2) 55
New Zealand Society for earthquake Engineering (see also Reconnaissance reports)

Marmara Sea Earthquake Reconnaissance Report. Sharpe, R.D.: Bradshaw, D.: Brown, N.: Van Dissen, R.: Kirkcaldie, D.: McManus, K.J.: Pham, T.: Stevenson, C. 33(2) 65

NZ Society for Earthquake Engineering Reconnaissance Team to Seattle, USA: The February 28, 2001 Nisqually Earthquake. Beetham, D.: Beattie, G.: Earl, B.: Duncan, D. 34(4) 253

Report of the New Zealand Reconnaissance Team to the area of the $17^{\text {th }}$ July 1998 Tsunami at Sissano Lagoon, Papua New Guinea. Goldsmith, P.: Barnett, A.: Goff, J.: McSaveney, M.: Elliott, S.: Nongkas, $\mathrm{M}$. 32(2) 102

The Chi-Chi, Taiwan Earthquake of 21 September 1999. Brunsdon, D.R.: Davey, R.A.: Graham, C.J.: Sidwell, G.K.: Villamor, P.: White, R.H.: Zhao, J.X.

The "Eje Cafetero" Earthquake, Colombia of January 25 1999. Restrepo, J.I.: Cowan, H.A. 33(1) 1 


\section{Reconnaissance reports}

Comparative preparedness in New Zealand and the Philippines for response to, and recovery from, volcanic eruptions: case studies from the 1991 Pinatubo eruption and the 1995-96 eruptions of Ruaphehu. Manville, V.: Johnston, D.: Stammers, S.: Scott, B. 33(4) 445

Earthquake building damage in developing countries: a review of recent reconnaissance reports. Charleson, A.W.: Fyfe, G.D. $\quad 34(2) 158$

Marmara Sea Earthquake Reconnaissance Report. Sharpe, R.D.: Bradshaw, D.: Brown, N.: Van Dissen, R.: Kirkcaldie, D.: McManus, K.J.: Pham, T.: Stevenson, C. 33(2) 65

NZ Society for Earthquake Engineering Reconnaissance Team to Seattle, USA: The February 28, 2001 Nisqually Earthquake. Beetham, D. : Beattie, G.: Earl, B.: Duncan, D. 34(4) 253

Report of the New Zealand Reconnaissance Team to the area of the $17^{\text {th }}$ July 1998 Tsunami at Sissano Lagoon, Papua New Guinea. Goldsmith, P.: Barnett, A.: Goff, J.: McSaveney, M.: Elliott, S.: Nongkas, M. 32(2) 102

The Chi-Chi, Taiwan Earthquake of 21 September 1999. Brunsdon, D.R.: Davey, R.A.: Graham, C.J.: Sidwell, G.K.: Villamor, P.: White, R.H.:
Zhao, J.X.
33(2) 105

The "Eje Cafetero" Earthquake, Colombia of January 25 1999. Restrepo, J.I.: Cowan, H.A. 33(1) 1

\section{Refurbishment and retrofitting}

From natural to cultural disaster: consequences of the post-earthquake rehabilitation process on the cultural heritage in Marathwada region, India. Jigyasu, R.

34(3) 237

Risk assessment and retrofit of existing buildings. Holmes, W.T. 33(3) 222
Direct displacement-based seismic design of concrete buildings. Priestley, M.J.N.: Kowalsky, M.J.

33(4) 421

Ductility demand for uni-directional and reversing plastic hinges in ductile moment resisting frames. Fenwick, R.C.: Dely, R.: Davidson, B.J. 32(1) 1

Improving the resistance of structures to earthquakes. Park, R. 34(1) 1

Influence of loading history on the response of a reinforced concrete beam. Ingham, J.M.: Liddell, D.: Davidson, B.J. $\quad 34(2) 107$

Monotonic non-linear analysis of reinforced concrete knee joints using strut-and-tie computer models. To, N.H.T.: Ingham, J.M.: Sritharan, S.

34(3) 169

Seismic behaviour and retrofit of pre-1970's as-built exterior beam-column joints reinforced by plain round bars. Liu, A.: Park, R. $\quad 34(1) 68$

Research (includes testing)

Ductility demand for uni-directional and reversing plastic hinges in ductile moment resisting frames. Fenwick, R.C.: Dely, R.: Davidson, B.J. 32(1) 1

Influence of loading history on the response of a reinforced concrete beam. Ingham, J.M.: Liddell, D.: $\quad$ Davidson, B.J. $\quad 34(2) 107$

Out-of-plane performance of a partially filled reinforced masonry wall with Ribraft ${ }^{\mathrm{TM}}$ floor. Singh, S.S.: Cooke, N.: Bull, D.K. 32(2) 90

Projects to be funded by the Earthquake Commission Research Programme 1999/2000 32(3) 182

Projects to be funded by the Earthquake Commission Research Programme 2001/2002 34(4) 336

Seismic behaviour and retrofit of pre-1970's as-built exterior beam-column joints reinforced by plain round bars. Liu, A.: Park, R. $\quad 34(1) 68$

\section{Reinforced concrete}


Seismic ratings for degrading structural systems.

$$
\text { Deam, B.L. }
$$

34(3) 214

\section{Seismic analysis and response}

Active, semi-active and hybrid control of structures. Soong, T.T.: Spencer, B.F. 33(3) 387

Analytical modelling of infilled frame structures - a general review. Crisafulli, F.J.: Carr, A.J.: Park, R. 33(1) 30

Monotonic non-linear analysis of reinforced concrete knee joints using strut-and-tie computer models. To, N.H.T.: Ingham, J.M.: Sritharan, S.

34(3) 169

Seismic ratings for degrading structural systems.

Deam, B.L.

34(3) 214

Understanding torsional phenomena in ductile systems. Paulay, T.

33(4) 403

\section{Seismic design}

Active, semi-active and hybrid control of structures. Soong, T.T.: Spencer, B.F. 33(3) 387

Design for low/moderate seismic risk. Pinto, P.E.

Direct displacement-based seismic design of concrete buildings. Priestley, M.J.N.: Kowalsky, M.J. 33(4) 421

Ductility demand for uni-directional and reversing plastic hinges in ductile moment resisting frames. Fenwick, R.C.: Dely, R.: Davidson, B.J.

$$
\text { 32(1) } 1
$$

Geotechnical factors in seismic design of foundations, state-of-the-art report. Romo, M.P.: Mendoza, M.J.: Garcia, S.R. 33(3) 347

Improving the resistance of structures to earthquakes. Park, R.
Influence of loading history on the response of a reinforced concrete beam. Ingham, J.M.: Liddell, D.: Davidson, B.J. 34(2) 107

Non-engineered construction in developing countries- an approach toward earthquake risk prediction. Arya, A.S. 33(3) 187

Out-of-plane performance of a partially filled reinforced masonry wall with Ribraft ${ }^{\mathrm{TM}}$ floor. Singh, S.S.: Cooke, N.: Bull, D.K. $\quad 32(2) 90$

Performance based seismic design. Priestley, M.J.N. 33(3) 325

Seismic design and retrofit of bridges. Kawashima, $\mathrm{K}$. 33(3) 265

Seismic ratings for degrading structural systems. Deam, B.L.

Understanding torsional phenomena in ductile systems. Paulay, T. 33(4) 403

Seismic hazards (includes hazard analysis)

Figures for the 12WCEE state-of-the-art paper "Seismic hazard evaluation" published in Vol. 33, No. 3, September 2000, pp325-346. Somerville, P. 33(4) 484

Preparation of the New Zealand earthquake catalogue for a probabilistic seismic hazard analysis. McGinty, P. 34(1) 60

Quantifying the hazard of large subduction thrust earthquakes in Hawke's Bay. Reyners, M. 33(4) 477

Seismic hazard evaluation. Somerville, P. 33(3) 371

\section{Seismology}

A model for the attenuation of peak ground acceleration in New Zealand earthquakes based on seismograph and accelerograph data. Cousins, W.J. : Zhao, J.X.: Perrin, N.D. $\quad 32(4) 193$

Attenuation of Modified Mercalli Intensity in New Zealand earthquakes. Dowrick, D.J.: Rhoades, D.A. 32(2) 55 
Azimuthal and regional variations of coda waves in New Zealand. Kozuch, M.J.: Chadwick, M.

32(3) 170

Earthquake hazard and risk assessment study for the Canterbury region: Outline of programme development. Kingsbury, P.A.: Pettinga, J.R.: Van Dissen, R.J. 34(4) 276

Earthquake source identification and characterisation for the Canterbury region, South Island, New Zealand. Pettinga, J.R.: Yetton, M.D.: Van Dissen, R.J.: Downes, G. $\quad 34(4) 282$

Modelling and earthquake response of Gisborne Post office site, New Zealand. Zhao, J.X.; Davenport, $\begin{array}{ll}\text { P.N.: McVerry, G.H. } & \text { 32(3) } 146\end{array}$

Preparation of the New Zealand earthquake catalogue for a probabilistic seismic hazard analysis. McGinty, P. 34(1) 60

Probabilistic seismic hazard assessment of the Canterbury region, New Zealand. Stirling, M.: Pettinga, J.R.: Berryman, K.: Yetton, M.D.

34(4) 318

Quantifying the hazard of large subduction thrust earthquakes in Hawke's Bay. Reyners, M.

33(4) 477

Station correction analysis for surface-wave magnitudes of New Zealand earthquakes. Rhoades, D.A.: Dowrick, D.J.

32(1) 21

The 1934 Pahiatua Earthquake sequence: analysis of observational and instrumental data. Downes, G.L.: Dowrick, D.J.: Smith, E.G.C.:

Berryman, K.R.

32(4) 221

The 1942 Wairarapa, New Zealand, Earthquakes: analysis of observational and instrumental data. Downes, G.L.: Dowrick, D.J.: Van Dissen, R.J.: Taber, J.J.: Hancox, G.T.: Smith, E.G.C.

34(2) 125

Weak motion attenuation of peak ground acceleration in the North Island, New Zealand. Pancha, A.: Taber J. 32(3) 125
Modelling and earthquake response of Gisborne Post office site, New Zealand. Zhao, J.X.; Davenport, P.N.: McVerry, G.H.

32(3) 146

Weak motion attenuation of peak ground acceleration in the North Island, New Zealand. Pancha, A.: Taber J.

32(3) 125

\section{Standards}

United States building code approach to variations in regional seismicity. Kircher, C.A. $33(1) 48$

\section{Volcanoes}

Comparative preparedness in New Zealand and the Philippines for response to, and recovery from, volcanic eruptions: case studies from the 1991 Pinatubo eruption and the 1995-96 eruptions of Ruaphehu. Manville, V.: Johnston, D.: Stammers, S.: Scott, B. 33(4) 445
L. Megget

January 2002

Soils and Ground response, geology 